\title{
Students' Perception on Learning English For Law Faculty Students at University of Batanghari Jambi
}

\author{
Suyadi*, Siti Aisyah \\ Universitas Batanghari Jambi \\ *Correspondence email: suyadi@ unbari.ac.id, ichatetrani@gmail.com
}

\begin{abstract}
This study is determined to analyze the negative and positive perceptions of Law Faculty students in learning English as a compulsory subject. There were 30 Law Faculty students at Second Semester Academic Year 2020/2021 involved in this research. The study adopted survey approach by giving questionnaire of 'Yes' or 'No' to explore five (5) indicators motivation, learning strategies, feeling, communication, and knowledge related to learning English. The participants of the study were Second Semester Students of Law Faculty of University of Batanghari. A convenient purposive sampling was used to allocate students' perception on learning English. The findings revealed that $83 \%$ of students shared positive perception on learning English at Law Faculty with the reasons that English could be useful for law practitioner. While, 27\% of students shared negative perception as they have personal reasons such as; do not like English language to be profession, English is difficult to learn, and English is difficult to pronoun.
\end{abstract}

Keywords: perception; law; practitioner; strategy

\begin{abstract}
Abstrak. Tujuan dari penelitian adalah untuk menganalisa persepsi dari para mahasiswa Fakultas Hukum Universitas Batanghari Jambi terhadap mata kuliah Bahasa Inggris untuk hukum. Jumlah mahasiswa semester dua Tahun Akademik 2020/2021 yang ikut berpartisipasi sebanyak 30 orang dengan memberikan kuisioner yang hanya memerlukan jawaban 'Ya', atau 'Tidak" dan terdiri dari lima (5) indikator utama. Lima indicator itu adalah motivasi, strategi pembelajaran, perasaan saat belajar Bahasa Inggris, komunikasi, dan ilmu pengetahuan mengenai Bahasa Inggris. Convinient purposive sampling digunakan dalam penelitian demi kelancaran penelitian dikarenakan terdapat enam (6) kelas mahasiswa semester satu di Fakultas Hukum Tahun Akademik 2020/2021 dengan jumlah 120 orang mahasiswa. Sampling jenis ini diambil berlatarbelakan pada bahwa peneliti yang mengampu di dua kelas ini sehingga dan memberikan kuisioner bagi mahasiswa yang bersedia mengisi kuisioner melalui link pada google.com. Hasil kuisioner menunjukkan terdapat $83 \%$ mahasiswa yang memiliki persepsi yang positif terdapat pembelajaran Bahasa Inggris untuk Fakultas Hukum yang berarti pula bahwa mereka sangat menyenangi dan memahami pembelajaran Bahasa Inggris untuk menunjang profesi mereka di masa depan. Sementara terdapat 27\% mahasiswa yang memiliki persepsi negative terhadap pembelajaran Bahasa Inggris karena memang mereka secara tradisional tidak menyenangi Bahasa Inggris dengan alasan bahwa Bahasa Inggris sulit dipelajari.
\end{abstract}

Keywords: persepsi; hokum; praktisi; strategi

\section{INTRODUCTION}

English has come to be an essential requirement for students and job seekers to set a better life. Consequently, many Indonesian learners are seriously learning English to compete in the global world. The position of teaching and learning English in Indonesia also gets a serious attention by Indonesian Government which is proven by putting English as the first foreign language in the secondary school since the beginning of the Independence (Sauwkut, 2003). Now, English is the compulsory subject learnt from elementary to university level.

In Faculty of Law, University of Batanghari, a lot terms in Law related to use English. Additionally, most of sources for their study including books and information about law are written in English first before another language. Based on the interviews conducted to students of Law Faculty of University of Batanghari most of students' difficulties are on the developing personality in English. On the other hand, most of the students confessed that English is important for their future career. Such perception will affect to the students' attitude in learning English. The attitude itself will affect to the learners behaviors (Alkaff, 2013). To come to the point, students' learning process is affected by perception.

The English as a Foreign Language teachers should respect and think about students' feelings, beliefs and behaviors before the cognitive abilities install into the students' knowledge because they are essential component in language learning (Abidin, 2012). Hence, the students' feelings, thoughts, and beliefs will affect their perception as a positive perception will affect positive attitude that should become the umbrella of language learning. In university level, English has been considered as a compulsory subject of Personality Development courses learnt in any faculty. Personality development means an educational vision to prepare the students a complete knowledge, attitude, academic career, and professional skills and also to have the competence in the development of English to face the global competence. Learning English is very important 
to prepare students face future career and develop their skills on their specific fields.

David Crystal (1997-2003: p.19) said that "English as a global language, wherever you travel, you see English signs and advertisements. Whenever you enter a hotel or restaurant in a foreign city, they will understand English, and there will be an English written menu". While, Robert M.Mckenzie (2017: p.20) stated that "learning English has been promoted by business and government as a strategy to internasionalise the nation". English is used in a specific field of profession gives an added-value of personal career in strengthening his/her influence in office (Suyadi, 2021).

Perception is the set of processes by which an individual becomes aware of and interprets information about many things. Perception refers to the way of someone tries to understand the world around us, gather the information through human's five sense organs. Qiong (2017) stated that perception is the whole process conscious human mind in drawing on the surrounding environment, the process of understanding the meaning of the stimulus while sensing of the object, events, or relationship between symptoms which are then processed by brain process. Moreover, Qiong (2017) argued that perception is a process experienced to achieve awareness or understanding of sensory information.

To support the above opinions, Walgito (2010) stated that perception is a process that is preceded by the sensing process, which is the process of receiving stimulus by individual through the sensory devices or also called sensory processes. Qiong (2017) proposed three stages of the perceptions, a) Selection is the first stage in the process of perception, where the environmental stimulus turns into meaningful experience, b) Organization is the second stage in the process of perception, where getting information is coming from the outside world needs to be arranged in a certain way by finding meaningful patterns. In organization stage has two characteristics, they are, first is the organizing process provides the structure of human's perception. In this stage, the raw stimuli from the outside world are place into meaningful experiences of structured humans. Second is the process shows that human perception has stability which means that after selecting a stimulus and putting it into a category, the selected stimulus becomes more durable. c) Interpretation is the third stage in human's perception, which means the process of attaching meaning to what is chosen by the stimulus. In general, human's perception is divided into two, the perception of the object (physical environment), and human perception (social perception). Students' perception is a process of mental to interpret or perceive and give meaning by using sense of Learning English. Lecturer's attitudes as perceived by the students may also have a positive effect on students' ability in learn, their self-esteem, and ultimately their academic succes.
Perception is the process of gathering information through our minds, organizing and making sense of it. Perception is the integrated condition of individual toward the stimuli received. So, someone thoughts, feelings, experiences will affect the perception. Our perception toward language mostly will be affected by the perception of our parents, teachers, and peers (Despagne, 2010). This perception also depends on our experience(s) with the language. Furthermore, he clarifies that perception is centered on the inner unconscious feeling from which students' attitude toward learning a language. Perception can be defined as regarding something "mentally" in a specified manner (Alkaff, 2013).

While, Hume (2000) divided perception in two different categories: sensations-outward sentiments; and reflection-inward sentiments. Psychologists, James Gibson, in the book of Cognitive Psychology In and Out of the Laboratory (2006) defined perception as a cognitive process that is used by persons to interpret and understand the world around it (the object). Gibson also explains that the perception is the process of giving meaning to the environment by the persons. Therefore, each person presents meaning to the stimulus differently to the same object. How people perceive the situation is often more important than the situation itself.

Despagne (2010) says that the concern of perception in language teaching is focus on reflection. Additionally, Despagne mentions that the notion of perception refers to group of attitudes and ideas, sometimes stereotypes that the person conveys in an unconscious way which affects the students' learning process. Kotler (2007) explained perception as a process of how someone selects sets and interprets the input of information to describe the whole objects. In general, perception is someone's perspective on something that will make a response of how a person will act.

Perception toward language, especially English, is the reflection of what someone thinks when she/he learns about English. Perception will result on how someone acts or attitude toward certain information. Someone's perception toward English is usually affected by the experiences in learning process.

\section{Perception and Learning English}

Perception and learning are relatively interconnected each other. As the definitions explained above, perception refers to how someone selects, sets and interprets the information. It also refers to someone's experience of the world. While learning in the other hand, is change in behavior that is a result of past experience or practice. So when one perceives something through his environment, he learns it and does it into practice (The Student Center Inc., 2013).

Someone will act in order to learn about the environment, and it is used to guide her/his actions in a daily life (Rieser, 2014). According to Marzano (1992), without positive attitudes and perceptions, students have 
little chance of learning proficiently. Perception in learning results in changes of getting information as a result of experience. Thus, perception includes the actions of the perceiver and the knowledge of information expanded. The information are gained by looking, listening, touching, walking and others.

Rieser (2014) stated that perceptual learning plays a central role in gaining information in the many different content areas. They are in the areas of work, everyday life, and also academic. In the reality, important example includes learning to identify different people, etc., and in this case is learning to differentiate the different element of speech in learning a language.

In language learning, perception is defined as a process of hearing, assimilating and understanding the sounds of language (Chandy, 2012). Psychologist tries to understand how learners of language recognize the language and use it in the daily conversation. The finding shows that there is knowledge based on perception and gained from perception (Chandy, 2012). It means that there are something learnt from outside that we establish contact with them through perception and action. Furthermore, Chandy (2012) stated that language learning is acquired from conscious effort and received through different perception. Create an interesting language learning atmosphere will help learners understand concepts and materials of target language that unfamiliar to them. This is one example of perception formed. In the early stages, learners may find a particular situation that makes them feel interested to learn English. An appropriate technique in learning English will form students' perception into positive and bring better results in language learning (Chandy, 2012).

To sum up, first sight will form perception in language learning that will result in attitude. Perception play important role in language learning. So that making interesting environment will help learners to form positive perception toward learning English.

\section{Perception Process}

Most psychologists describe the perception process in three stages. According to Star (2009) It includes selection, organization and interpretation. The human perceptual process begins from stimuli and ends with behavior. The perceiver, the perceived, and the setting have important role in the selection process. The perceiver refers to a person that decides what he or she needs, wants and expects to see. The selection process is influenced by the physical, mental and emotional conditions of the perceiver. The perceived, in the other hand, is certain general attributes of the perceived object, person or idea. Setting as what is perceived in normal.

The second stage is named organization. This is done in three ways. They are classification, figureground differentiation, and closure (Star, 2009). In the classification, someone tends to classify gender, race, gender, education, occupation, and others. According to Star (2009), figure-ground differentiation helps the perceiver to distinguish figure (dominant features) from ground (surrounding, competing stimuli). Perceptual closure, in other hand, works when someone received incomplete information. In effect, the mind fills in the gap.

The last stage of perception process is interpretation. Interpretation is influenced by beliefs, assumptions, values, attitudes and past experiences. These beliefs, assumptions, values, attitudes, past learning and experiences combine to form an individual references to form new perceptions based on Star stated.

\section{Factors Affecting Perception}

Perception is influenced by some factors. Robins, R.W. (2007) divided the factors affect perception into internal and external factors. The first is internal factors. Internal factors consist of feelings, motivation of student, process of learning, feeling, individual personalities, prejudices, desire or expectation, attantion (focus), and interest. While external factors consist of family background, information obtained knowledge and the culture around (communication), size, and opposites.

Robins, R.W. (2007) noticed three factors affect perception. They are individual, target of perception, and situation, and he added other psychological factors that are also important in the perception. The psychological factors consist of emotions, impressions and context. Furthermore Robins, R.W.(2007) conveyed that the formation of the perception is greatly influenced by the information which is first obtained. The first unhappy experience will affect the formation of perception. However, the stimulus faced by human is changing, so that the perception can change based on the stimulus received.

\section{Learning English}

Burns in Sauwkut (2010) defines learning as a relatively permanent change in behavior. Behavior includes process such as thinking, attitudes and emotions. Burns includes motivation in this definition of learning. Burns emphasizes the importance of experiences, meanings, problems-solving and the development of insights in learning. Furthermore, he states that someone has subjective interpretations in different contexts.

Learning is described as a relatively permanent change in behavior based on an individual's interactional experience with his/her environment. Learning is an important form of personal adaptation. The process of learning is noted by changes in behavior or even the development of new responses through interactions or experiences with the environment. English language learners are the students who has first language is a language other than English, and who may require educational supports to assist them in attaining proficiency in English. In addition, these students may be western born or recently arrived from other countries. They come from diverse backgrounds and school 
experiences and have a wide variety of strengths and needs.

\section{Learning English in Indonesia}

Indonesian have learnt English as a foreign language. Kachru (1992) displays the model of English into three circles (Lauder, 2008). Furthermore, in the model, he divides these circles into inner circle, the outer circle, and expanding or extending circle. The inner circle refers to the "traditional bases" of English countries including UK, USA, Ireland, Canada, Australia, and New Zealand. The outer (or extended) circle refers to the earlier spread of English in non-native settings, where the language has become a part of the country's important institutions, and it plays an important 'second language' role in a multilingual setting. It includes Singapore and Malaysia, India, and over fifty other territories. Expanding or extending circle refers to nations which recognize the importance of English as an international language. Indonesia belongs to this last circle which also includes China, Japan, Greece and Poland.

English has no wide used in society of Indonesia. It is not used as a medium of communication in official domains like government, the law courts, and the education system according to Lauder, (2008). However, English is important because the extent of the role such as in economics and business, international relations, the media, education, communications and international travel and safety. Sauwkat (2003) stated that the function of English in Indonesia will not change too much. It is very needed for the development of science and technology, and for international relationship in varies aspects.

\section{The Importance of Learning English}

According to an Essay gotten from a website Dutta (2012), there are several reasons why English is important language to learn. English is important because it is the most spoken official language in the world. It is the main language used in international affairs. English is the primary language of trade and commerce. In many countries most tourism authorities and other officials speak English to interact and engage with tourists and immigrants. English is also used in many computer's applications and programs, social media networks and websites. Software manuals, hardware installation guides, product fact sheets, and electronics devices are always available in English first before other languages.

English is primary language instructions used for most international students in universities and colleges in the world. The institutions like top business schools, medical centers and advanced study institutes use English in every activity. Scientists, engineers, technologists, and others use English to publish their researches and journals. In addition, knowing English opens up the widest possible job and employment opportunities in many countries and markets. Someone who masters English will get better opportunities then who does not. That's all the importance of learning English based on the essay reported by Dutta (2012).

\section{International Language}

International language is a language achieves a genuinly global status when it develops a special role that is recognized in every country. This might seem like stating the obvious, but it is not, for the notion of 'special role' has many facets. Such a role will be most evident in countries where large numbers of the people speak the language as a mother tongue. However, no language has ever been spoken by a mother-tongue majority in more than a few countries, (spanish leads, in this respect, in some twenty countries, chiefly in Latin Amerrica), so mother-tongue use by itself cannot give a language global status.

According to David Crystal (1997: p.4) stated that to achieve such status, a language has to be taken up by other countries arround the world. They must decided to give it a special place within their communities, even though they may have few (or no) mother-tongue speakes.there are two main ways in which this can be done. Firstly, a language can be made the official language of a country, to be used as a medium of communication in such domains as government, the law courts, the media, and the aducational system. To get on these societies, it is essential to master the official languageas early in life as possible. Such a language is often described as a "second language", because it is seen as a complement to a persons mother-tongue, or first language. The role of an official language is today best illistrated by English, which now has some kind of special status in over seventy countries, such as Ghana, Nigeria, India, Singapura, and Vanuantu.

Secondly, a language can be made a priority in a country's foreign-language, even though this language has no official status. It is becomes a language which children are most likely to be taught when they arrive in school, and the one most available to adults who-for whatever reason-never learned it, or learned it badly in their early in educational years. Although we might expect people from a country where English has a some sort of official status to be more competent in the language than those where it has none, simply ground of greater exposure, it turns out that this is not always so. In a world where children are being born to parents who communicate each other through a lingua franca learned as a foreign langauge.

The research revealed that most students believe that English is a subject that is easy to learn while arguing that grammer is difficult to learn. Students' perception also maintained that English is easy because it is the only subject they have much knowledge in, even before starting school. Not with standing this claim of knowing English, and it not being difficult, students 
irronically indicated that English is one of the subject that they fail most in Indonesia.

The reason given by some students for the failure was attributed to a strict marking scheme for English. As to what aspect of the subject was more difficult. Students indicated essay writing, comprehension, and grammar in order of difficulty. According to Jin and Cortazzi (2002) said that "... students view their academic life in a collective way in which they care about relationships, and harmony in their learning and in their communication with others". The reseaarcher feels that the picture pained about the level of confidence of the students may not be entirelyaccurate about how students perceive themselves. Having alerted the students that the exercise was part of a research that was ongoing. It is suspected that the modesty of students might have played a part in their responses to the questionaire item on confidence.

\section{METHODOLOGY OF RESEARCH}

This chapter presents the discussions of the research method. It is including type of the reseach, setting of the research, participant of the research, instrumentation, research procedure, technique of data collection, technique of data analysing, and checking data trustworthiness.

\section{Research Design}

This research is categorized as describtive qualitative research that discribes the current status of relationships at the time of study. This research gives a perception about English learning situation that happened in the second semester at Law Faculty of University of Batanghari about students' perception on learning English for faculty of law. According to Sugiyono (2016) "qualitative research method is a research method that is based on the philosophy postpositivisme, is used to examine the condition of the naturalobjects, (as his opponent is experimental) wherethe researcher is the key instrument. "qualitative research is research procedures which produce describtive data in the form of word written or spoken of the peopleand behaviour that can be observed." Bodgan and Taylor, (1998).

The data of the research are students perception toward English as an International Language in the classroom at the second semester of law faculty in Batanghari University.

\section{Setting of the Research}

This research was carried out at University of Batanghari. The campus is located Jl. Slamet Riyadi Broni Telanai Pura Jambi . this campus was taken as the research location by considering some factors. First, the campus is located near toward my boarding house, the researcher also interested to research the second semester in Batanghari University to find how the students' perception on learning English for faculty of law at second semester in University of Batanghari, the researcher have been familiar with the second semester of Law Faculty. furthermore, it made easier to get the data because the lecturers are openhand to the research.

\section{Subject of the Research}

Participant of the research is a generalization area consisting of: objects/subjects that have certain qualities and characteristics defined by the researcher to be studied and then drawn conclutions the subject of the second semester in Law Faculty at University of Batanghari, it consists of one class.

\section{Instrumentation}

The key instrument of this study is the researcher itself. Patton (2002) states that in qualitative inquiry the researcher hold a role as the instrument of the research. She is the one who has responsible in collecting, interpreting, analyzing and concluding the data. In addition, the researcher also used some other instruments to collect the data namely: observation checklist and questionaires. Observation checklist which was replied and used by the researcher during the classroom observation used. And the last, questionaires was also used to indicate whether the Law Faculty student are like or not about learning English.

\section{Research Prosedure}

During the research, the researcher indicated how students' perception toward learning English for Law Faculty students. This research observed whether student of Law Faculty at University of Batanghari are truly have a positive or negative perception on learning English. By using an observation checklist and questionaires as the main instruments are useful to get information about their perception toward learning English. Due to the fact, the lecturers who teaching English in Law Faculty not too detail teaching English, so that's why the students in Law Faculty still in hard to understand English, whereas sometimes their books written by English language.

\section{Technique of Data Collection}

Based on the explanation above, in collecting data the researcher used two technique. Data was taken from primary data, it is meant direct from researcher source data. The technique of the research are: observation and questionaire. Resercher does observation about interviewed students' perception toward English as an International language.

\section{Observation}

According to Arikunto (2010) said that observation is a way to complete the data collection format instrument. Format observations as compiled based on an interview of items observation to behaviour not omly record but listen and judge what happens. Next, Sugiyono (2016), passive participation observation 
is the researcher present at the scene ofaction but it does not interact or participate. Notice that qualitative data could be much more than just words or text. Photographs, videos, sound recording, and so on, can be considered qualitative data. The researcher used passive participation observation.

The observation of students' perception toward learning English for Law Faculty. In this case the researcher uses line. The observation consists of one meeting. In this research, the researche want to know how is the students' perception on learning English for faculty of law at the second semester of Law Faculty in University of Batanghari in academic year 2020/2021.

Table 1. The Specifications of the Observations

\begin{tabular}{|c|c|c|}
\hline $\begin{array}{l}\text { Perception } \\
\text { process of } \\
\text { Student } \\
\end{array}$ & $\begin{array}{l}\text { Aspect Affecting } \\
\text { Perception }\end{array}$ & $\begin{array}{c}\text { Activity } \\
\text { Observed }\end{array}$ \\
\hline Selection & $\begin{array}{l}\text { Internal } \\
\text { - Physical, mental, } \\
\text { emotional } \\
\text { condition, feeling, } \\
\text { motivation of } \\
\text { student, process } \\
\text { of learning, needs } \\
\text { values, and } \\
\text { individual } \\
\text { personalities. } \\
\text { External } \\
\text { - Family } \\
\text { bachground, } \\
\text { information } \\
\text { obtained, } \\
\text { knowledge, and } \\
\text { the culture around } \\
\text { (communication) }\end{array}$ & $\begin{array}{l}\text { Student's listen } \\
\text { to the lecturer's } \\
\text { explanation } \\
\text { about the materi } \\
\text { of English then } \\
\text { the student give } \\
\text { the feedback } \\
\text { like student ask, } \\
\text { make the } \\
\text { conclusion, and } \\
\text { make it to be } \\
\text { motivation to } \\
\text { student. Etc. } \\
\text { Student connect } \\
\text { each other to } \\
\text { share the } \\
\text { knowledge } \\
\text { about English } \\
\text { that have been } \\
\text { given from the } \\
\text { lecturer. }\end{array}$ \\
\hline Organization & $\begin{array}{l}\text { Classification } \\
\text { - Gender, race, } \\
\text { education, } \\
\text { occupation. } \\
\text { Figure-ground } \\
\text { differentiation } \\
\text { - Competing } \\
\text { stimulus } \\
\text { Perceptual Closure } \\
\text { - Thinking, mind } \\
\text { filss the gap. }\end{array}$ & $\begin{array}{l}\text { Lecturer's } \\
\text { question } \\
\text { maintain the } \\
\text { student to } \\
\text { competing } \\
\text { stimulus by the } \\
\text { question. } \\
\text { Students active } \\
\text { in the class }\end{array}$ \\
\hline Interpretation & $\begin{array}{l}\text { Influenced by beliefs, } \\
\text { assumptions, values, } \\
\text { attitudes, and past } \\
\text { learning. }\end{array}$ & \\
\hline
\end{tabular}

Source: Star (2009)

Based on the explanation above the researcher concludes that observation is technique of data collection it is a complex process and not only human behaviour could be a subject but it also the process or work. The researcher uses passive participant observation.

\section{Questionaires}

According to Sugiyono (2012: p.199) questionaires is techniques of data collection is done by giving a set of questions or a written statement to the respondent to answer. The researcher used to questionaires to get the data students perception toward learning English as an International language. The researcher distributed the questionaires to the respondent to be fulfilled by them.

The student were given a clear explanation about tha way to fill the questionaires. The researcher observed the respondents while they were filling it. The questionaires should be answer based on the opinion.

According to Humby (2020) questionaires is list of questions to be answer by a group of people, especially to get facts, or for survey. In the study, the questionaire is given to the students to find numerical data of their perception. The questionaire consist of 10 items about student perception toward learning English as a global language. Each the items in the list required the student to give answer by giving a 'check list' to tjhe column 'yes' or 'no', prepare on the right sideof every item. If the case questionaire in the questionaire has not ever happened, it is also an actual response of the student toward the situation given.

According to Humby (2020) divided the factors affect perception into internaland external factors. Internal factor consits of feelings, motivation of student, process of learning, feeling, individual personality, prejudices, desir or expectations, attention (focus), and interest. While external factor consits of family background, information obtained, knowledge, and the culturearound (communication), size and opposite. Below is the specification of observation:

Table 2. Specifications of Questionnaire

\begin{tabular}{clcl}
\hline No & \multicolumn{1}{c}{ Indicators } & Items & \multicolumn{1}{c}{ No. Questionnaire } \\
\hline 1 & Motivation & 11 & $1,3,4,13,14,15,17,18,27,28$, \\
2 & Learning Strategies & 4 & $2,7,9,12$ \\
3 & Feeling & 11 & $5,10,11,16,19,21,22,23,24,25,26$ \\
4 & Communication & 2 & 6,30 \\
5 & Intelligence/Knowledge & 2 & $8,29,20$ \\
\multicolumn{2}{c}{ Total } & 30 & \\
\hline
\end{tabular}

Source: Widiastuti \& Wibowo (2009)

From the specification of questionaires, the student have the same questionaires and do it at the same time. Student should answer the questionaires by using or putting the tick mark $(\sqrt{ })$ on the 'yes or no'.

The questionnaire of this research is conclud of perception toward learning English. Where perception about English and learning English are connected each other. According to Marzano (1992), without positive attitudes and perceptions, students have little chance of learning proficiently. Perception in learning results in changes of getting information as a result of experience. 
Thus, perception includes the actions of the perceiver and the knowledge of information expanded. The information are gained by looking, listening, touching, walking and others.

As the definitions above, perception refers to how someone's experience of the world. While Learning in the other hand is change in behaviour that is the result of past experience or practice. So, when someone perceives something through his environment, he learns it and does it into practice based on The Student Center:2013.

\section{Technique of the Data Analysis}

According to Humby, K (2020) the data analysis describes the statistical design that was used and the statistical analysis that were undertaken. It is usually not necessity to describe these procedure step-by-step. If the statistical test used were common omes, then the test may simply be named and its source referenced. More unusual approaches require more detail. Next, Bodgan (1998) said that after collection of data, it must analyze, to find important data and learning about data, decide what can that data to tell for another people. Furthermore, Stainback in Sugiyono (2012: p.244), data analysis is critical tothe qualitative research process.it is to recognize,study and understanding of interrelationships and concept in your data that hypothesis, assertions can be developed and evaluated.

The researcher in the technique of data analysis, the researcher presents it in term of percentage by Sugyiono (2006: p.43) , to analyze the questionaire result, the formula are as follow:

$P=\frac{F}{N} \times 100 \%$

Where:

\section{$P=P E R C E N T A G E$ \\ $F=F R E Q U E N C Y$ \\ $N=$ TOTAL NUMBER \\ $100 \%=$ ROUND NUMBER}

From those term of percentage, the researcher can apply it to this research. The researcher take the sample to the students of law faculty the second semester it consist of 25 students in the class. So to know how the percentage of the questionnaire result from those sample it will be shown in the following table:

Table 3. Percentage of Questionnaire Result

\begin{tabular}{llc}
\hline No & Number of Student & Percentage \\
\hline 1 & 25 & - \\
\hline
\end{tabular}

It can be seen from using Sugiono's percentage above, the researcher apply it based on the formula:

$P=\frac{25}{30} \times 100 \%$

$=83 \%$
From those explanation, 25 is the number of students or the frequency of the population, 30 is the totaly number of questionnaire and the $83 \%$ is the result percentage of questionnaire to measure the totaly of the student who choose yes or no statement. This research is aimed to know the students' perception toward learning English at the second semester of Law Faculty.

\section{FINDINGS}

To attain an objective research the researcher takes 25 students of Law Faculty in Batanghari University at the second semester in academic year $2020 / 2021$ as the sample. To know the number of respondent, in this research the totally of students are 25 person. It is described in the following table;

Table 4. Respondent profile and Respondent Percentage

\begin{tabular}{ll}
\hline No & Respondent Name \\
\hline 1 & Sindi Feroliza \\
2 & Bagus Fatriyanto \\
3 & Niati Arsela \\
4 & M. Roycal Rizky \\
5 & Ibnu Rayhan \\
6 & Hendric Noprialdi \\
7 & Kms. M.Sahit Al-Qodri \\
8 & Serly Novita Rahmanisa \\
9 & Bintang Akbar Rahmadi \\
10 & Ffajar Arya Saputra \\
11 & Annisa Marcellina \\
12 & Renisyah Cinta Azzahra \\
13 & Shelly Aprilia Putri \\
14 & Agnes Farazia Maryana \\
15 & Elva Melvina Oktasari \\
16 & Samuel Bina Aresando S \\
17 & Farly Alvino \\
18 & Chas Ananda \\
19 & Wulan Nabila \\
20 & Syarifah Nur Aliza \\
21 & Silva Aulia Khalid \\
22 & Farah Nadipa Khairunnisa \\
23 & Joya Nur Agustine \\
24 & Wendi Afrian Munthe \\
25 & Marisa \\
\hline$R e s$ &
\end{tabular}

Respondent name in at Second Semester Academic Year 2020/2021

Table 5. Respondents' Percentage

\begin{tabular}{lll}
\hline No & Number of Student & Percentage \\
\hline 1 & 25 & $83 \%$ \\
\hline
\end{tabular}

\section{Data Description}

In this part showed the collecting data through questionnaire. The questionnaire is used to know the students' perception toward learning English as an International language at the second semester at Law Faculty of University of Batanghari in academic year 2020/2021.

\section{a) Questionnaire}

After doing the research, start from collecting and analyzing the data, so the data which collected in this 
research is the students' percentage of the students' perception toward learning English as an International language. Those data were collected through questionnaire distribution to the 25 respondent which were chosen as sample in this research. The questionnaire is used the scale of Guttman that using Yes or No statement. The statement of Guttman scale not only using Yes or No but also use Disagree-Agree, Sure-Unsure, Positive-Negative, and Ever-Never. But in this research the questionnaire used Yes or No. It can be shown from the following table;

Table 6. The Statement of Questionnaire

\begin{tabular}{ll}
\hline No & Statement of Questionnaire \\
\hline $\mathbf{1}$ & Yes-No \\
$\mathbf{2}$ & Agree-Disagree \\
$\mathbf{3}$ & Sure-Unsure \\
$\mathbf{4}$ & Positive-Negative \\
$\mathbf{5}$ & Ever-Never \\
\hline Guttman Scale (1944-1959)
\end{tabular}

Table above is tell about the scale or type of Guttman scale, what are the catagories on Guttman scale, not only use Yes No but other words also available on that scale. In this research the researcher used Yes - No statement because the researcher used qualitative method and using Yes-No statement is suit from this research. Measuring of Yes-No statement will be shown on the table below;

Table 7. Measuring of Percentage

\begin{tabular}{lll}
\hline No & Statement & Percentage Measure \\
\hline $\mathbf{1}$ & No & $1 \%-41 \%$ \\
$\mathbf{2}$ & Yes & $42 \%-83 \%$ \\
& Totally Percentage & $83 \%$ \\
\hline
\end{tabular}

Below is the table of student on questionnaire, how many who chose Yes statement and how many students who chose No statement, in the table below also show the percentage of the number of student.

Table 8. Student Number of Questionnaire

\begin{tabular}{lllll}
\hline No & $\begin{array}{c}\text { Yes } \\
\text { Statement }\end{array}$ & Percentage & $\begin{array}{c}\text { No } \\
\text { Statement }\end{array}$ & Percentage \\
\hline 1 & 23 & $77 \%$ & 2 & $7 \%$ \\
2 & 19 & $63 \%$ & 6 & $20 \%$ \\
3 & 17 & $57 \%$ & 8 & $27 \%$ \\
4 & 16 & $53 \%$ & 9 & $30 \%$ \\
5 & 16 & $53 \%$ & 9 & $30 \%$ \\
6 & 14 & $47 \%$ & 11 & $37 \%$ \\
7 & 9 & $30 \%$ & 16 & $53 \%$ \\
8 & 20 & 67 & 5 & $17 \%$ \\
9 & 16 & $53 \%$ & 9 & $30 \%$ \\
10 & 15 & $50 \%$ & 10 & $33 \%$ \\
11 & 18 & $60 \%$ & 7 & $23 \%$ \\
12 & 16 & $53 \%$ & 9 & $30 \%$ \\
13 & 22 & $73 \%$ & 3 & $10 \%$ \\
14 & 17 & $57 \%$ & 8 & $27 \%$ \\
15 & 15 & $50 \%$ & 10 & $33 \%$ \\
16 & 16 & $53 \%$ & 9 & $30 \%$
\end{tabular}

\begin{tabular}{lllll}
17 & 15 & $50 \%$ & 10 & $33 \%$ \\
18 & 11 & $37 \%$ & 14 & $47 \%$ \\
19 & 16 & $53 \%$ & 9 & $30 \%$ \\
20 & 22 & $73 \%$ & 3 & $10 \%$ \\
21 & 18 & $60 \%$ & 7 & $23 \%$ \\
22 & 13 & $43 \%$ & 12 & $40 \%$ \\
23 & 20 & 675 & 5 & $17 \%$ \\
24 & 20 & $67 \%$ & 5 & $17 \%$ \\
25 & 17 & $57 \%$ & 8 & $27 \%$ \\
26 & 20 & $67 \%$ & 5 & $17 \%$ \\
27 & 20 & $67 \%$ & 5 & $17 \%$ \\
28 & 19 & $63 \%$ & 6 & $20 \%$ \\
29 & 21 & $70 \%$ & 4 & $13 \%$ \\
30 & 18 & $60 \%$ & 7 & $23 \%$ \\
\hline
\end{tabular}

Number of student on questionnaire

From the table 4.3 (student number of questionnaire) above the explanation are below;

Table 9. Answer of the students' statement No.4.6

Percentage of the students' answer based on the statement number 1 (belajar bahasa Inggris penting karena itu membuat asaya lebih berpendidikan dalam materi menguasai bahasa hukum).

\begin{tabular}{llll}
\hline No & $\begin{array}{c}\text { Students' } \\
\text { statement }\end{array}$ & $\begin{array}{c}\text { Student } \\
\text { Frequency }\end{array}$ & Percentage \\
\hline $\mathbf{1}$ & Yes & 23 & $77 \%$ \\
$\mathbf{2}$ & No & 2 & $7 \%$ \\
\hline
\end{tabular}

Based on the table above can be concluded that the students' perception toward learning English as an International language is positive because 23 respondents $77 \%$ answered Yes And 2 respondents 7\% Answered No, this condition shows that the students perception toward learning English as an International language at the second semester at Law Faculty of University of Batanghari is positive. They think that English is important for increase law language in English.

\section{Table 10. Answer of the students' statement No.4.10}

Percentage of the students' answer based on the statement No.5 (berbicara bahasa Inggris dimanapun membuat saya merasa cemas)

\begin{tabular}{llll}
\hline No & $\begin{array}{c}\text { Students' } \\
\text { statement }\end{array}$ & \multicolumn{1}{c}{$\begin{array}{c}\text { Student } \\
\text { Frequency }\end{array}$} & Percentage \\
\hline $\mathbf{1}$ & Yes & 16 & $53 \%$ \\
$\mathbf{2}$ & No & 9 & $30 \%$ \\
\hline
\end{tabular}

Based on the table above can be concluded that the students' perception toward learning English as an International language is positive because 16 respondents 53\% answered Yes And 9 respondents 30\% Answered No, this condition shows that the students perception toward learning English as an International language at the second semester at Law Faculty of 
University of Batanghari is positive. They think use English is not make them feel worried exactly pleasing.

\section{Table 11. Answer of the student's statement No.4.11}

Percentage of the students' answer based on the statement No.6 (belajar bahasa Inggris membuat saya mempunyai hubungan yang baik dengan teman difakultas hokum)

\begin{tabular}{llll}
\hline No & $\begin{array}{l}\text { Students' } \\
\text { statement }\end{array}$ & $\begin{array}{l}\text { Student } \\
\text { Frequency }\end{array}$ & Percentage \\
\hline $\mathbf{1}$ & Yes & 14 & $47 \%$ \\
$\mathbf{2}$ & No & 11 & $37 \%$ \\
\hline
\end{tabular}

Based on the table above can be concluded that the students' perception toward learning English as an International language is positive because 14 respondents $47 \%$ answered Yes And 11 respondents 37\% Answered No, this condition shows that the students perception toward learning English as an International language at the second semester at Law Faculty of University of Batanghari is positive. They think that English is making them have a good relationship with their friends at law faculty.

Table 12. Answer of the students' statement No.4.16

Percentage of the students' answer based on the statement No.11 (belajar bahasa asing seperti bahasa Inggris sangat menyenanggkan)

\begin{tabular}{llll}
\hline No & $\begin{array}{l}\text { Students' } \\
\text { statement }\end{array}$ & $\begin{array}{l}\text { Student } \\
\text { Frequency }\end{array}$ & Percentage \\
\hline $\mathbf{1}$ & Yes & 18 & $60 \%$ \\
$\mathbf{2}$ & No & 7 & $23 \%$ \\
\hline
\end{tabular}

Based on the table above can be concluded that the students' perception toward learning English as an International language is positive because 18 respondents $60 \%$ answered Yes And 7 respondents 23\% Answered No, this condition shows that the students perception toward learning English as an International language at the second semester at Law Faculty of University of Batanghari is positive. They think that English is fun.

\section{Table 13. Answer of the student's statement No.4.18}

Percentage of the students' answer based on the statement No.13 (ketika saya mendengar seseorang berbicara bahasa Inggris dengan baik dalam kelas saya, membuat saya ingin mempraktekkan kemampuan bahasa Ingris saya dengannya)

\begin{tabular}{llll}
\hline No & \multicolumn{1}{c}{$\begin{array}{c}\text { Students' } \\
\text { statement }\end{array}$} & $\begin{array}{c}\text { Student } \\
\text { Frequency }\end{array}$ & Percentage \\
\hline $\mathbf{1}$ & Yes & 22 & $73 \%$ \\
$\mathbf{2}$ & No & 3 & $10 \%$ \\
\hline
\end{tabular}

Based on the table above can be concluded that the students' perception toward learning English as an International language is positive because 22 respondents $73 \%$ answered Yes And 3 respondents 10\% Answered No, this condition shows that the students perception toward learning English as an International language at the second semester at Law Faculty of University of Batanghari is positive. They think that English is maintaining their spirit to always learn about English, even to practice it in the law class.

\section{Table 14. Answer of the students' statement No.4.22}

Percentage of the students' answer based on the statement No.17 (belajar bahasa Inggris membuat saya lebih percaya diri dalam mengekspresikan diri didalam kelas hukum).

\begin{tabular}{llll}
\hline No & \multicolumn{1}{c}{$\begin{array}{c}\text { Students } \\
\text { statement }\end{array}$} & $\begin{array}{c}\text { Student } \\
\text { Frequency }\end{array}$ & Percentage \\
\hline $\mathbf{1}$ & Yes & 15 & $50 \%$ \\
$\mathbf{2}$ & No & 10 & $33 \%$ \\
\hline
\end{tabular}

Based on the table above can be concluded that the students' perception toward learning English as an International language is positive because 15 respondents 50\% answered Yes And 10 respondents 33\% Answered No, this condition shows that the students perception toward learning English as an International language at the second semester at Law Faculty of University of Batanghari is positive. They feel more confident to express their self in the law class.

\section{Table 15. Answer of the students' statement No.4.24}

Percentage of the students' answer based on the statement No.19 (saya selalu menunda mengerjakan PR bahasa Inggris saya)

\begin{tabular}{llll}
\hline No & $\begin{array}{c}\text { Students' } \\
\text { statement }\end{array}$ & $\begin{array}{c}\text { Student } \\
\text { Frequency }\end{array}$ & Percentage \\
\hline $\mathbf{1}$ & Yes & 16 & $53 \%$ \\
$\mathbf{2}$ & No & 9 & $30 \%$ \\
\hline
\end{tabular}

Based on the table above can be concluded that the students' perception toward learning English as an International language is negative because 16 respondents 53\% answered Yes And 9 respondents 30\% Answered No, this condition shows that the students perception toward learning English as an International language at the second semester at Law Faculty of University Batanghari is negative. They always do their English homework on time.

\section{Table 16. Answer of the students' statement No.4.28}

Percentage of the students' answer based on the statement No.23 (saya menikmati semua kegiatan dalam kelas bahasa Inggris saya), 


\begin{tabular}{llll}
\hline No & $\begin{array}{c}\text { Students' } \\
\text { statement }\end{array}$ & \multicolumn{1}{c}{$\begin{array}{c}\text { Student } \\
\text { Frequency }\end{array}$} & Percentage \\
\hline $\mathbf{1}$ & Yes & 20 & $63 \%$ \\
$\mathbf{2}$ & No & 5 & $17 \%$ \\
\hline
\end{tabular}

Based on the table above can be concluded that the students' perception toward learning English as an International language is positive because 20 respondents $63 \%$ answered Yes And 5 respondents $17 \%$ Answered No, this condition shows that the students perception toward learning English as an International language at the second semester at Law Faculty of University of Batanghari is positive. They really enjoy learning English.

\section{Table 17. Answer of the students' statement No.4.30}

Percentage of the students' answer based on the statement No.25 (saya kurang nyaman ketika saya harus berbicara dalam kelas dengan bahasa Inggris)

\begin{tabular}{llll}
\hline No & \multicolumn{1}{c}{$\begin{array}{c}\text { Students' } \\
\text { statement }\end{array}$} & $\begin{array}{c}\text { Student } \\
\text { Frequency }\end{array}$ & Percentage \\
\hline $\mathbf{1}$ & Yes & 17 & $57 \%$ \\
$\mathbf{2}$ & No & 8 & $27 \%$ \\
\hline
\end{tabular}

Based on the table above can be concluded that the students' perception toward learning English as an International language is negative because 17 respondents 57\% answered Yes And 8 respondents 27\% Answered No, this condition shows that the students perception toward learning English as an International language at the second semester at Law Faculty of University of Batanghari is negative. They do not feel pleasant when they have to speak in English in English lesson.

\section{Table 18. Answer of the students' statement No.4.34}

Percentage of the students' answer based on the statement No.29 (menurut sya, orang yang menguasai bahasa lebih dari satu bahasa itu sangat berpengetahuan luas apalagi mengetahui istilah asing dalam bahasa hukum)

\begin{tabular}{llll}
\hline No & $\begin{array}{c}\text { Students' } \\
\text { statement }\end{array}$ & $\begin{array}{c}\text { Student } \\
\text { Frequency }\end{array}$ & Percentage \\
\hline $\mathbf{1}$ & Yes & 21 & $70 \%$ \\
$\mathbf{2}$ & No & 4 & $13 \%$ \\
\hline
\end{tabular}

Based on the table above can be concluded that the students' perception toward learning English as an International language is positive because 21 respondents $70 \%$ answered Yes And 4 respondents $13 \%$ Answered No, this condition shows that the students perception toward learning English as an International language at the second semester at Law Faculty of University of Batanghari is positive. They think that English will help them to have the opportunity to master the knowledge especially in law faculty.

\section{Table 19: Answer of the students' statement No.4.35}

Percentage of the students' answer based on the statement No.30 (belajar bahasa Inggris membantu saya lebih baik berkomunikasi dalam bahasa Inggris ketika saya bertemu dengan mahasiswa hokum lainnya diluar kelas atau diluar nengri)

\begin{tabular}{llll}
\hline No & $\begin{array}{c}\text { Students' } \\
\text { statement }\end{array}$ & \multicolumn{1}{c}{$\begin{array}{c}\text { Student } \\
\text { Frequency }\end{array}$} & Percentage \\
\hline $\mathbf{1}$ & Yes & 18 & $60 \%$ \\
$\mathbf{2}$ & No & 7 & $23 \%$ \\
\hline
\end{tabular}

Based on the table above can be concluded that the students' perception toward learning English as an International language is Positive because 18 respondents $60 \%$ answered Yes And 7 respondents 23\% Answered No, this condition shows that the students perception toward learning English as an International language at the second semester at Law Faculty of University of Batanghari is positive perception. They think learning English can help them to make a communication in English language when they meet other students' law outside country.

\section{Discussion}

After conducting the observation and gave the questionnaire to the students, the researcher found the result of the students' perception toward learning English as an International language at the second semester at Law Faculty of University of Batanghari.

First, the students' perception toward learning English is Positive. It was shown that on the Table.4.6 that 23 respondents $77 \%$ answered yes and 2 respondents $7 \%$ answered no. Second, the students' perception toward learning English is Positive. It was shown that on the Table.4.7 that 19 respondents $63 \%$ answered yes and 6 respondents 20\% answered no. Third, the students' perception toward learning English is Positive. It was shown that on the Table.4.8 that 17 respondents $57 \%$ answered yes and 8 respondents $27 \%$ answered no. Fourth, the students' perception toward learning English is Positive. It was shown that on the Table. 4.9 that 16 respondents $53 \%$ answered yes and 9 respondents $30 \%$ answered no. Fifth, the students' perception toward learning English is Positive. It was shown that on the Table.4.10 that 16 respondents $53 \%$ answered yes and 9 respondents $30 \%$ answered no. Sixth , the students' perception toward learning English is Positive. It was shown that on the Table.4.11 that 14 respondents $47 \%$ answered yes and 11 respondents $37 \%$ answered no. Seventh, the students' perception toward learning English is Negative. It was shown that on the Table.4.12 that 9 respondents $30 \%$ answered yes and 16 respondents $53 \%$ answered no. Eighth, the students' perception toward learning English is Positive. It was shown that on the Table.4.13 that 20 respondents $67 \%$ answered yes and 5 respondents $17 \%$ answered no. 
Ninth , the students' perception toward learning English is Positive. It was shown that on the Table.4.14 that 16 respondents $53 \%$ answered yes and 9 respondents $30 \%$ answered no. Tenth , the students' perception toward learning English is Positive. It was shown that on the Table.4.15 that 15 respondents $50 \%$ answered yes and 10 respondents $30 \%$ answered no. Eleventh, the students' perception toward learning English is Positive. It was shown that on the Table.4.16 that 18 respondents $60 \%$ answered yes and 7 respondents $23 \%$ answered no. Twelvth, the students' perception toward learning English is Positive. It was shown that on the Table.4.17 that 16 respondents 53\% answered yes and 9 respondents $30 \%$ answered no. Thirteenth, the students' perception toward learning English is Positive. It was shown that on the Table.4.18 that 22 respondents $73 \%$ answered yes and 3 respondents $10 \%$ answered no. Fourteenth, the students' perception toward learning English is Positive. It was shown that on the Table.4.19 that 17 respondents 53\% answered yes and 8 respondents $27 \%$ answered no.

Fifteenth, the students' perception toward learning English is Positive. It was shown that on the Table.4.20 that 15 respondents $50 \%$ answered yes and 10 respondents $33 \%$ answered no. Sixteenth, the students' perception toward learning English is Positive. It was shown that on the Table.4.21 that 16 respondents $53 \%$ answered yes and 9 respondents $30 \%$ answered no. Seventeenth, the students' perception toward learning English is Positive. It was shown that on the Table.4.22 that 15 respondents $50 \%$ answered yes and 10 respondents 33\% answered no. Eightteenth, the students' perception toward learning English is Negative. It was shown that on the Table.4.23 that 11 respondents $37 \%$ answered yes and 14 respondents $47 \%$ answered no. Nineteenth, the students' perception toward learning English is Negative. It was shown that on the Table.4.24 that 16 respondents $53 \%$ answered yes and 9 respondents $30 \%$ answered no. Twentieth, the students' perception toward learning English is Positive. It was shown that on the Table.4.25 that 22 respondents $73 \%$ answered yes and 3 respondents $10 \%$ answered no. Twentione, the students' perception toward learning English is Negative. It was shown that on the Table.4.26 that 18 respondents $60 \%$ answered yes and 7 respondents $23 \%$ answered no. Twentysecond, the students' perception toward learning English is Negative. It was shown that on the Table.4.27 that 13 respondents $43 \%$ answered yes and 12 respondents $40 \%$ answered no. Twenty-third, the students' perception toward learning English is Positive. It was shown that on the Table.4.28 that 20 respondents $63 \%$ answered yes and 5 respondents $17 \%$ answered no.

Twenty-four, the students' perception toward learning English is Negative. It was shown that on the Table. 4.29 that 20 respondents $67 \%$ answered yes and 5 respondents $17 \%$ answered no. Twenty-five, the students' perception toward learning English is
Negative. It was shown that on the Table.4.30 that 17 respondents $57 \%$ answered yes and 8 respondents $27 \%$ answered no. Twenty-six, the students' perception toward learning English is Negative. It was shown that on the Table.4.31 that 20 respondents $67 \%$ answered yes and 5 respondents $17 \%$ answered no. Twenty-seven, the students' perception toward learning English is Positive. It was shown that on the Table.4.32 that 20 respondents $67 \%$ answered yes and 5 respondents $17 \%$ answered no. Twenty-eight, the students' perception toward learning English is Positive. It was shown that on the Table.4.33 that 19 respondents $63 \%$ answered yes and 6 respondents $20 \%$ answered no. Twenty-nine, the students' perception toward learning English is Positive. It was shown that on the Table.4.34 that 21 respondents $70 \%$ answered yes and 4 respondents $13 \%$ answered no. Thirtieth, the students' perception toward learning English is Positive. It was shown that on the Table.4.35 that 18 respondents $60 \%$ answered yes and 7 respondents $23 \%$ answered no.

\section{CONCLUSION}

After the resercher discuss and explain the information in this research entittle "Students' Perception Toward Learning English for Law Faculty students at the Second Semester at Law Faculty of University of Batanghari in Academic Year 2020/2021". So the researcher can take the conclusion as below:

The students' perception in English lesson at the second semester of Law Faculty of University of Batanghari tends to be Positive Perception, based on the questionnaire given to the students and based on the data from this research that measure from the Guttman scale and measuring of percentage. Most of the student realize the importance of learning English at Law Faculty and also it useful for their future especially to face the globalization era right now.

\section{SUGGESTION}

From finding and the discussions, the researcher would like to give some suggestion as followed:

a. The students should have the positive perception about English because it is useful for them selves especially for the future to face the globalization era, and also in right now internet is using English language for information, education, or communication. Even in education world, the English language is used for every book sheet or journal international. English also for the first language in the world as a communication in each country.

b. The lecturers should give more pay attantion to their students about the importance of English. They can give support and advice in order to the students to have possitive perception toward English. The lecturers also should give the learning strategies that more interesting to the students, may be give the new effort for students enjoy in English class. 


\section{REFERENCES}

Abidin, D. M. (2012, February). EFL Students' Attitude toward Learning English Language: The Case of Libyan Secondary School Students. Asian Social Science, 119-134.

Alkaff, A. A. (2013). Students Attitudes and perceptions towards Learning English. Arab World English Journal, 106-121.

Arikunto, S. 2010. Prosedur Penelitian Suatu Pendekatan Praktik. Jakarta: Rineka Cipta.

Asra, D. M. (2014). English Teachers' Perception towards National Examination: A survey to 31 SMA English Teachers in Jambi. Jambi.

Boutellier, R., Gassmann, O., Raeder, S., \& Zeschky, M. (2013). How do Qualitative and Quantitative Research Differ? Zurich: ETH.

Bogdan, R. \& Taylor, SJ. (1998). Introduction to Qualitative Research Methods: a guidebook and resource. New York: Wiley.

Chandy, M. (2012, November 9). Improving Perception and Language Acquisition. Retrieved September 10, 2014, from Education: http://www.brighthubeducation.com/teaching-tipsforeignlanguages/86262 perception-languagelearning-and-methodology/

Crystal, David (1988). The English Language. London: Penguin. ISBN 0-14- 013532-4.

- (1997). English as a Global Language. Cambridge: Cambridge

University Press. ISBN 0-521-59247-X.

Despagne, C. (2010). The Difficulties of Learning English: Perception and Attitudes in Mexico. Canadian and International Education, 55-74.

Dutta, P. (2012). eHaw. Retrieved September 9, 2014, from The Importance of Learning English:http://www.ehow.com/about_5249789_i mportancelearni ng-english.html

Harold, H., \& Beall, D. (1984). Toward the Development of A Children's Science Curiosity Measure. Journal of Research in Science Teaching, 425-436.

Hume, D. (2000). An Enquiry Cocerning Human Understanding. Retrieved March 9, 2014, from ecmd.nju.edu.cn/UploadFile/9/4301/vw02sc.do

Humby, K., Christina Jerosch-Herold, Horton, S. (2020) Development and preliminary validation of a patient-reported outcome measure for conversation partner schemes: the Conversation and Communication Questionnaire for People with Aphasia (CCQA), Aphasiology, 34:9, 11121137, DOI: $\underline{10.1080 / 02687038.2020 .1738160}$

Hutchinson, T. \& Waters, A. (1986). English for Specific Purposes. Cambridge University Press

Cortazzi, M. \& Jin, L. (2002) Cultures of Learning: The social construction of educational identities. In D. C. S. Li (Ed.), Discourses in search of members, in honor of Ron Scollon. Lanham: University Press of America, pp. 49-78.
Johnson, B. \& Christensen, L. (2008). Educational Research. Sage Publications.

Juwita, M. (2014). Non-English Programme Students' Perception toward Learning English: A Survey at Faculty of Teacher Training and Education. Jambi

Gibson, James (2014). The theory of Affordances. Google Scholar. Google Scholar. ISBN 9781317811886. Retrieved 1 December 2014.

Kachru, Braj B. (1992). "World Englishes: approaches, issues and resources". Language Teaching. 25 (1): 1-14. doi:10.1017/S0261444800006583. ISSN 1475-3049.

Kotler, Philip (2007). Manajemen Pemasaran. Edisi Kedua Belas. Jakarta. Indeks

Lauder, A. (2008). The Status and Function of English in Indonesia: A review of Key Factors. Makara, Sosial Humaniora , 9-20.

Marzano, R. J. (1992). Chapter 2. Dimension 1: Positive Attitudes and Perceptions About Learning. Retrieved October 9, 2014, from Books: http://www.ascd.org/publications/books/61192107 /chapters/Dimension- $1 @$ Positive-Attitudes-andPerceptions-About-Learning.aspx

McKenzie, R., Gilmor, A. (2017). "The people who are out of 'right' English": Japanese university students' social evaluations of English language diversity and the internationalisation of Japanese higher education. International Journal of Applied Linguistics

Ndlwana, M. (1991). A Critical Analysis of Problems Encountered by Senior Secondary School Pupils in the Reading and Interpretation of 1:50,000 Topographical Maps and AerialPhotograps with Special Reference to Black Pupils in Transkei. Rhodes University.

Nunan, D. (1992). Research Methods in Language Learning. United States of America: Press Syndicate of the University of Cambridge.

Patton, M.Q. (2002). Qualitative Research and Evaluation Methods, $3^{\text {rd }}$ edn. Thousand Oaks: Sage

Qiong, O. U. (2017). A brief introduction to perception. Studies in Literature and Language, 15(4), 18-28. https://doi.org/10.3968/10055

Ramadhan, B. F. (2009). Gambaran Persepsi. Retrieved October $\quad 9, \quad 2014, \quad$ from lib.ui.ac.id/file?file=digital/125416-S-5609-

Gambaran\%20persepi...pdf

Rieser, J. J. (2014). Learning - Perceptual Processes. Retrieved September 12, 2014, from State University.com:

http://education.stateuniversity.com/ pages/2167/Learning-PERCEPTUALPROCESSES.html

Sapp, S. G. (2013). Validity and Reliability. Retrieved September 23, 2014, from Social Science 
Research

Method:

http://.soc.iastate.edu/sapp/sapp.html

Sauwkut, R. (2010). Learning Theories: A Review. Oxford Business \& Economics Conference Program, 1-11.

Soleimani, H., \& hanafi, S. (2013). Iranian Medical Students' Attitudes towards English language Learning. International Research Journal of Applied and Basic Sciences , 3816-3823.

Suyadi, (2016). English for Specific Purposes for Accounting Students. International Journal of Innovation and Research in Educational Sciences, Volume 3, Issue 2, ISSN (Online) 2349-5219 https://www.ijires.org/adinistrator/components/co $\underline{\mathrm{m} \_j \text { jesearch/files/publications/IJIRES_584_FINA }}$ $\underline{\text { L.pdf }}$

Sugiyono, (2016). MetodologiPenelitianKuantitatif, Kualitatif, dan R\&D. Bandung: CV Alfabeta.

Star. (2009, August 22). The Stages of Human Perceptual Process. Retrieved March 27, 2014, from Socyberty:

http://socyberty.com/psychology/thestageshuman-perceptualprocess. (2009, August 22).

Robins, R.W. (2007). Handbook of Research Methods in Personality Psychology. The Guilford Press, New York.

Trochim, W. M. (2008, October 20). Types of Reliability. Retrieved September 20, 2004, from Research Method Knowledge Base: http://www.socialresearchmethods.net/kb/reltypes. php

Walgito, Bimo. 2010. Pengantar Psikologi Umum. Yogyakarta: Andi.

Wibowo, Y. Mulyanto, J., \& Kringos, D.S. (2021). Exploring general practitioners' perceptions about the primary care gatekeeper role in Indonesia. https://doi.org/10.1186/s12875-020-01365-w

Xamuel. (2009, September 18). 10 Reasons Why English is A hard Language. Retrieved July 9, 2014, from Xamuel.com: $\quad$ http://www.xamuel.com/10reasons-why-english 